\title{
Integrating Learning Outcomes Assessment In Information Systems Curriculum Revisions
}

Ali F. Emdad, Morgan State University, USA

\begin{abstract}
This paper examines various dimensions of outcomes assessment and analyzes the assurance of learning process that is mandated by business schools' accrediting agency, AACSB International. We describe learning outcomes assessment, various types of assessment, and why it is important to align assessment with learning goals and instruction. Information systems model curriculum 2002 and AACSB International share similar goals in terms of outcomes assessment. IS programs should make sure that feedback from the assessment process along with input from internal and external sources, are used to make curricular adjustments.
\end{abstract}

Keywords: Assessment, Learning Outcomes, Assurance of Learning, IS Curriculum, Program-Level Assessment

\section{INTRODUCTION}

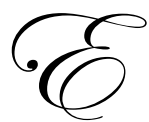

ach year, states collectively spend more than $\$ 70$ billion to support higher education, but useful information about what students learn in college is not readily available. Without reliable information about college level learning outcomes, policymakers cannot determine which investments or strategies are most cost-effective, and students, families, and employers do not have information that can improve their decisions about the quality of different providers of higher education. There have been calls for the development of minimum general educational learning outcomes for undergraduates educated at public colleges or universities, as well as the requirement to assess the outcomes. However, there is already a good deal of consensus among institutions about these goals as reported by the National Governors Association (2007).

This paper examines various dimensions of outcomes assessment and analyzes the AACSB International's assurance of learning (AoL) process through a conceptual framework. We describe AoL from the information systems program perspective and illustrate how MIS educators can engage in the assurance of learning process.

Most business schools have used indirect measures such as surveys of alumni and employers, as well as course-embedded assessment to satisfy the AACSB standards. In its 1991 standards, AACSB International introduced the concept of "outcomes assessment" as a requirement for accredited institutions. Since 2003, the emphasis has shifted and AACSB (2007a, p.60) has mandated that accredited schools "...formulate specific learning goals and conduct appropriate direct assessment of learning for the purposes improving curricula when deficiencies or opportunities for improvement are found." As the general discussion on how to define and measure outcomes for various programs in business schools intensifies, the question no longer focuses on whether to assess, but rather what to assess and how best to perform it. Driscoll and Wood (2004) assert that faculty cannot simply be told that assessment is important, meaningful, and full of insight for their teaching. When they view assessment as the responsibility of "someone else," a responsibility prompted by external forces and one with little relevance to their pedagogical roles, they usually resist involvement. Although there is a significant number of research papers on assessment in general, only episodic discipline-specific assessments of programs are reported in the literature. The field of Information Systems is not an exception. 


\section{WHAT IS ASSESSMENT?}

Assessment refers to a set of processes that measure the outcome of student learning. We may view assessment as an ongoing process aimed at understanding and improving student learning. It involves making our expectations explicit and public; setting appropriate criteria, benchmarks, and high standards for learning quality; systematically gathering, analyzing, and interpreting evidence to determine how well performance matches those expectations and standards; and using the resulting information to document, explain, and improve performance. Angelo (1995) believes that when it is embedded effectively within larger institutional systems, assessment can help focus our collective attention, examine our assumptions, and create a shared academic culture dedicated to assuring and improving the quality of higher education. A substantial body of assessment literature exists that covers institutional and program accountability with related work on measuring and improving student achievement. Halpern (1987) and Erwin (1991) have described design and implementation issues in assessment. Other researchers including Staik and Rogers (1996) offer ways to use student achievement data to strengthen programs and at same time, Magruder and Young (1996) show how results on the ETS Major Field Test in Psychology led to curriculum modification and general-education curriculum changes based on outcomes on standardized examinations. According to Livingston and Zieky (1982), standardized test scores have been used in making decisions on matters such as graduation, course completion, the need for remedial instruction, and advanced placement. In the business area, accounting appears to be the program most involved in assessment, possibly because of the outgrowth of experience with the certified public accountant (CPA) examination. Issues related to the design of assessment processes have been studied by DeMong, Lindgren, and Perry (1994) as well. Apostolou (1999) argued that program assessment can be improved by using proven practices from other disciplines. Data from administration of the Educational Testing Service's (ETS) Major Field Test in Business has been used by Allen and Bycio (1997) to address test appropriateness, and Mirchandani, Lynch, and Hamilton (2001) used grade point averages and compared them with scores on the ETS business field test for assessment of student learning. In September 2006, the Commission on the Future of Higher Education formed by U.S. Department of Education (2006, p.24) made a number of recommendations, including the suggestion that "the collection of data from public institutions allowing meaningful interstate comparison of student learning should be encouraged and implemented in all states". The combined efforts of state and federal government as well as the mandates of accreditation agencies will bring to sharp focus the need for meaningful and continuous assessment strategies at the program level.

\section{GLOBAL PERSPECTIVE OF ASSURANCE OF LEARNING (AOL)}

Learning is a complex process and accrediting bodies have placed importance on measuring student learning outcomes. The goal is that assessment of student learning outcomes should be an important element in academic program reviews and accreditation. However, assessment is not an end in itself but a vehicle for educational improvement. What AACSB termed "assurance of learning (AoL) standards" is based on two principles of accountability and continuous improvement. According to AACSB International (2007b), measures of learning can assure the external constituents, such as potential students, trustees, public officials, supports, and accreditors, that the organization meets its goals. Learning and assessment processes must form a feedback loop to provide useful information for continuous improvement. Figure 1 is a conceptual model of assurance of leaning.

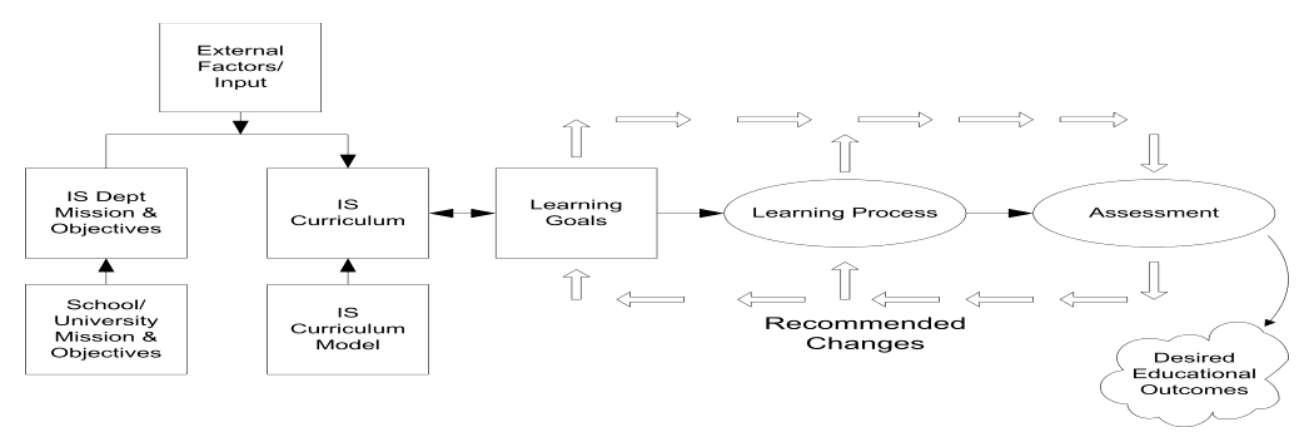

Figure 1. A Conceptual Model of Assurance of Learning 
Although there are discipline and subject-specific accreditation standards for information systems such as ABET CAC (2007), many IS departments have not opted to be assessed through these agencies. Information Systems is considered a business discipline and comes under the AACSB accreditation standards. Regardless of what agency is assessing the IS program, at the program level, the accreditation standards mandate that the program has documented, measurable objectives, including expected outcomes for graduates. Evidence needs to be presented that the program regularly assesses its progress against its objectives and uses the results of the assessments to identify program improvements and to modify the program's objectives. Moreover, it makes good professional sense to engage in self-assessment and discovery to improve effectiveness of teaching and learning.

The outcomes assessment process should include:

1. Definition of student learning goals and objectives

2. Alignment of curricula with the adopted goals

3. Identification of instruments and measures o assess learning

4. Collection, analysis, and dissemination of assessment information

5. Using assessment information for continuous improvement including documentation that the assessment process is being carried out in a systematic, ongoing basis. (AACSB, 2007c)

Research has demonstrated that students learn more if they engage actively in learning. Pascarella and Terenzini (2005) assert that if students spend more time studying, interact frequently with faculty and with student peers concerning intellectual matters, experience high expectations for their persistence and achievement, and encounter and interact with diverse people and ideas. Implementing an assurance of learning program is an involved and challenging process. It is implemented at the program level and generally should cover four to ten learning goals for the IS degree program. AACSB International stipulates that through a systematic process all goals must be assessed at least twice in a five-year cycle to support curriculum redesign (AACSBa, 2007). We can use assurance of learning outcomes in an IS program based on the same standards that is used for the business school with the addition of a few discipline-related learning outcomes. Gorgone et al. (2002) point out to the changes in the IS field and its maturity that is reflected in various IS model curricula that have evolved over the past two decades. Several characteristics of the IS profession have been relatively constant over time and have been integrated into IS 2002 model curriculum. These are:

1. IS professionals must have a broad business and real world perspective.

2. IS professionals must have strong analytical and critical thinking skills.

3. IS professionals must have interpersonal communication and team skills and have strong ethical principles.

4. IS professionals must design and implement information technology solutions that enhance organizational performance.

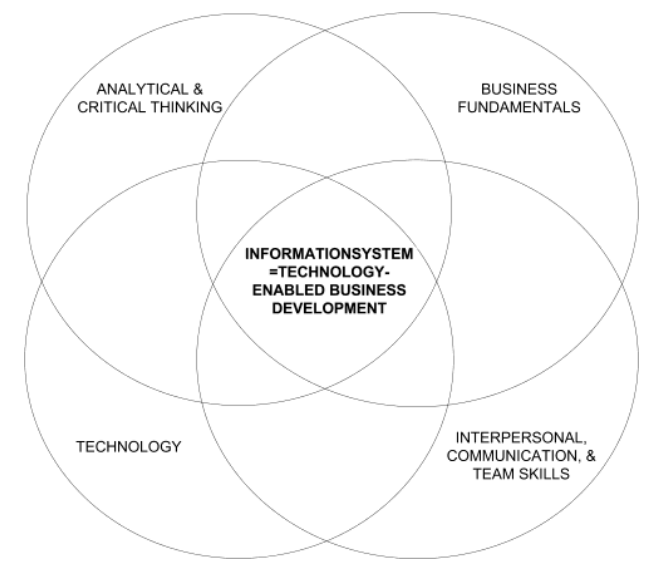

Figure 2. High-Level Categorization of IS Graduate Exit Characteristics (Gorgone et.al.) 
Characteristics 1, 2, and 3 match the expected learning outcomes that a majority of business schools have most frequently used in their assessment processes (AACSBa, 2007). Feedback from the assessment process along with input from internal and external sources should be used to make curricular adjustments. This continuous improvement process assures that IS graduates meet the learning outcomes expectations. The concern is making sure that we translate information to action. The results of assessment should lead to the proper decision making and acceptance of changes by the faculty and ultimately implemented in the curriculum. Figure 2 shows the learning outcomes goals recommended by IS 2002 Model Curriculum.

\section{IS PROGRAM PRIORITIES AND ASSESSMENT METHODS}

In order to provide effective educational programs at the undergraduate or graduate levels, teaching and learning activities need to be aligned with student learning outcomes. Course-level and program-level assessment systems must move toward the same goals. The program goals and priorities determine what types of assessments are needed and what evidence can be gathered to demonstrate achievement of learning outcomes. Wiggins and McTighe (2005) have developed the Understanding by Design (UbD) framework for curriculum planning, design, and assessment. They have delineated a three stage process that starts with identification of desired results, determining acceptable evidence, and then planning learning experiences and instruction. UbD proposes a multifaceted approach with the six facets of understanding (explanation, interpretation, application, perspective, empathy, and self-knowledge). The facets combine with backward design to provide a practical framework for designing curriculum, assessment, and instruction. This backward design approach requires setting program goals and priorities first. For example, what knowledge and skills will the student need to demonstrate understanding in learning outcomes in an information systems program?

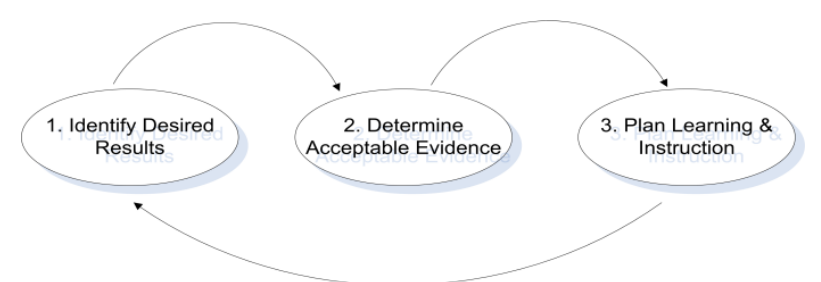

Figure 3. Understanding by Design (UbD) Framework (Wiggin \& McTighe, 2005)

If a desired learning outcome of an Information Systems program is to be able to demonstrate understanding of planning for an information systems application development, then students need to learn systems development life cycle (SDLC) concepts, Work Breakdown Structures (WBS) development and uses, Responsibility Matrix, uses and reason for using Gantt charts. Students need to know how to develop a list of activities and predecessors, cost and time estimation, network diagrams, and how to make a risk register. These skills are needed for planning an IS application development. A variety of learning resources, such as textbooks, videos, industry guides and brochures, and guest speakers from a local IT firm, provide rich combination of diverse and engaging experience for students. In terms of assessment, it is clear what needs to be assessed through quizzes and tests and why a team project is needed to assess students' overall understanding. Greer (2001) asserts that the instructor needs to ask the question, what kind of evidence is needed to measure attainment of learning objectives? Both direct and indirect assessment techniques should be used. Direct assessment methods consist of informal checks for understanding, observations, tests and quizzes, academic prompts, and performance tasks. Indirect assessment may be carried out through alumni surveys, exit surveys of graduating students, and surveys of employers who recruit graduates of IS programs.

\section{CONCLUSION}

Educational institutions are increasingly held accountable for student learning. Assurance of learning involves implementing an assessment initiative to develop student learning outcomes, design assessment instruments to measure learning, analyze the measurement results to identify learning insufficiencies, and establish feedback 
mechanisms to modify the curriculum to address the insufficiencies. For IS programs to be effective in their educational mission, assurance of learning provides an appropriate framework to incorporate assessment of learning outcomes in their curricula. Further research is needed to develop innovative assessment techniques in IS programs.

\section{AUTHOR INFORMATION}

Professor Ali Emdad, a 2007 Fulbright Scholar, is the Founding Chair of the Department of Information Science and Systems in the Graves School of Business and Management at Morgan State University. He has more than thirty two publications and has organized three international conferences with more than 1500 participants. He holds a Ph.D. from Case Western Reserve University and has completed the renowned executive management and leadership education programs at Harvard and Yale universities. Prior to joining academia, Dr. Emdad worked at Kennecott Corporation as an IT specialist. In 2003, Morgan State University awarded him the Iva G. Jones Medallion Mantle, the highest honor for outstanding teaching, scholarship and service.

\section{REFERENCES}

1. AACSB International (2007a), “AACSB Assurance of Learning Standards: an Interpretation,” November 20, pp. 1-16.

2. AACSB International (2007b), "Eligibility Procedures and Accreditation Standards for Business Accreditation," Tampa, Florida, AACSB International.

3. AACSB International (2007c), “Assessment Resource Center," Retrieved on December 12, 2007 from www.aacsb.edu/resource_centers/assessment/default.asp.

4. ABET Computing Accreditation Commission, (2007), "Criteria For Accrediting Computing Programs," Baltimore, MD, pp. 1-23.

5. About the ISA Exam (2007), Retrieved on November 28 from http://isa.is.byuh.edu/about.html.

6. Allen, J. S., and Bycio, P. (1997), "An evaluation of the Educational Testing Service Major Field Achievement Test in Business," Journal of Accounting Education, 15, 503-514.

7. Angelo, T.A. (1995), American Association for Higher Education AAHE Bulletin, November 1995, p.7.

8. Apostolou, B. A. (1999), "Outcome assessment. Issues in Accounting Education, 14, pp.177-197.

9. DeMong, R. F., Lindgren, J. H., Jr., and Perry, S. E. (1994), "Designing an assessment program for accounting," Issues in Accounting Education, 9, pp.11-27.

10. Driscoll, Amy and Wood, Swarup (2004), "Creating Learner-Centered Assessment: A Faculty-Driven Process," Peer Review, 7(1), pp.12-15.

11. Erwin, T. D. (1991), “Assessing student learning and development: A guide to the principles, goals, and methods of determining college outcomes," Jossey-Bass, San Francisco.

12. Greer, L. (2001), "Does Changing the Method of Assessment of a Module Improve the Performance of a Student?" Assessment and Evaluation in Higher Education 26, 2.

13. Gorgone, J.T., Davis, G.B., Valacich, J.S., Topi, H., Feinstein, D.L., and Longenecker, Jr., H.E. (2002), "IS 2002 Model Curriculum and Guidelines for Undergraduate Degree Programs in Information Systems," Association for Information Systems. Retrieved November 16, 2007 from http://www.is2002.org.

14. Halpern, D. F. (Ed.). (1987), “Student Outcomes Assessment: What Institutions Stand To Gain,” JosseyBass, San Francisco.

15. Livingston, S. A., and Zieky, M. (1982), "Passing Scores, A Manual For Setting Standards of Performance On Educational And Occupational Tests," Educational Testing Service, Princeton, NJ.

16. Magruder, W. J., and Young, C. C. (1996), "Value Added Talent Development In General Education," In T. W. Banta, J. P. Lund, K. E. Black, and F. W. Oblander (Eds.), Assessment in practice: Putting principles to work on college campuses, Jossey-Bass, San Francisco, pp. 169-171.

17. National Governors Association (2007), "Higher Education Accountability for Student Learning," NGA Center for Best Practices, Washington, D.C., pp. 1-11.

18. Pascarella, E. T., and P. T. Terenzini. (2005), "How College Affects Students. Volume 2: A Third Decade of Research," Jossey-Bass, San Francisco. 
19. Staik, I. M., and Rogers, J. S. (1996), "Listening To Your Students," In Assessment In Practice: Putting Principles To Work On College Campuses,” In T. W. Banta, J. P. Lund, K. E. Black, and F. W. Oblander (Eds.), Jossey-Bass, San Francisco, pp. 132-135.

20. U.S. Department of Education, (2006), "A Test of Leadership: Charting The Future Of U.S. Higher Education," U.S. Department of Education, Washington, DC.

21. Wiggins, G. and McTighe, J. (2005), "Understanding by Design," Association for Supervision and Curriculum Development, Alexandria, VA.

22. Young, C. C. (1996), "Triangulated Assessment of The Major," In Assessment In Practice: Putting Principles To Work on College Campuses," T. W. Banta, J. P. Lund, K. E. Black and F. W. Oblander (Eds.), Jossey-Bass, San Francisco, pp. 101-104.

\section{NOTES}

